\title{
Resveratrol Ameliorates Atherosclerosis Induced by High-fat Diet and LPS in ApoE-/- Mice and Inhibits the Activation of CD4+ T Cells by Regulating the Expression of Dnmt
}

\section{Liyu Zhou}

Nanjing University of Chinese Medicine https://orcid.org/0000-0001-9950-4177

Jun Long

Nanjing University of Chinese Medicine

\section{Yuting Sun}

Nanjing University of Chinese Medicine

Weikai Chen

Nanjing University of Chinese Medicine

Runze Qiu

Nanjing First Hospital

Dongping Yuan ( $\square$ annieyuan99@163.com )

\section{Research}

Keywords: Resveratrol, Atherosclerosis, CD4+ T cells, DNA methyltransferase

Posted Date: February 20th, 2020

DOI: https://doi.org/10.21203/rs.2.24028/v1

License: (c) (i) This work is licensed under a Creative Commons Attribution 4.0 International License. Read Full License 


\section{Abstract}

Background Atherosclerosis (AS), which characterized with the accumulation of lipids on the vessel wall, is the pathological basis of many cardiovascular diseases (CVD) and seriously threatens human health. Resveratrol (RES) has been reported to be benefit for AS treatment. This research aimed to observe the effects of RES on AS induced by high-fat diet (HFD) and LPS in ApoE -/- mice and investigate the underlying mechanism. Methods ApoE -/- mice were fed with HFD companied with LPS to induce AS and RES was administrated for 20 weeks. Splenic CD $4+T$ cells were cultured and treated with anti-CD3/CD28 together with LPS, and RES was added. Serum lipids and the atherosclerotic areas of aortas were detected. The activation of CD $4+T$ cells were investigated both in vivo and in vitro and the expression of DNA methyltransferases (Dnmt) in CD4 + T cells were measured.

Results In vivo, administration of RES prevented HFD and LPS induced dysfunction of serum lipids including TC (total cholesterol), TG (triglyceride), LDL-C (low density lipoprotein cholesterol) and HDL-C (high density lipoprotein cholesterol), ameliorated the thickened coronary artery wall and decreased the areas of atherosclerotic lesion on aortas. Besides, RES decreased the number of CD $4+T$ cells in peripheral blood, decreased the expression of CD25 and CD44, but not affected the expression of Lselectin (CD62L). In vitro, RES decreased the expression of Ki67, CD25 and CD44 in CD4 + T cells. Moreover, RES increased the secretion of IL-2, IL-10 and TGF- $\beta 1$, decreased IL-6. In addition, RES decreased both the mRNA and protein level of Dnmt1 and Dnmt3b in CD4 + T cells. Conclusion These results indicated that RES ameliorated AS induced by HFD companied with LPS in ApoE -/- mice and inhibited the proliferation and activation of CD4 + T cells by regulating the expression of Dnmt1 and Dnmt3b.

\section{Introduction}

Atherosclerosis (AS) is a chronic inflammatory disease[1,2]. AS induces the progression of cardiovascular diseases (CVD) such as coronary heart disease and cerebral infarction, seriously threatens human health[3]. Therefore, prevent the progression of AS is vital for keeping cardiovascular health.

The pathogenesis of AS is complex. Dyslipidemia is a risk factor for the progression of AS and keep the serum lipids in a normal range is an important way to prevent AS[4]. In addition, chronic inflammation, which accelerates the accumulation of immune cells on vessel wall, is another risk factor of AS[5]. Immune cells in atherosclerotic lesions producing mainly pro-inflammatory cytokines and accelerating the formation of an inflammatory microenvironment $[6,7]$. CD $4^{+} T$ cells are the most abundant $T$ cells in atherosclerotic lesion and play important roles throughout the stages of atherogenesis[8]. CD ${ }^{+} \mathrm{T}$ cells as an important component in adaptive immune responses, powerfully regulates the inflammatory process $[9,10]$. Naïve $C D 4^{+} T$ cells highly express of $L$-selectin (CD62L), and CD62L was down-regulated when $\mathrm{CD} 4^{+} \mathrm{T}$ cells were activated under inflammatory stimulation[11]. Moreover, CD25 and CD44 are activation biomarkers of $\mathrm{CD} 4^{+} \mathrm{T}$ cells and are potently induced after the activation[12]. Activated $\mathrm{CD} 4^{+} \mathrm{T}$ cells further activate the immune response, increase the secretion of pro-inflammatory cytokines like 
interleukin-6 (IL-6), and decrease IL-10 and transforming growth factor- $\beta 1$ (TGF- $\beta 1)[13,14,15]$. The activation of $\mathrm{CD} 4^{+} \mathrm{T}$ cells is an important process in the inflammation progression in AS and prevent the activation of $\mathrm{CD}^{+} \mathrm{T}$ cells would be expected to prevent inflammation and ameliorate AS[16].

Resveratrol (RES), a natural polyphenol presented in grapes, mulberries, peanuts, rhubarb, and in several other plants[17, 18], is a potential food ingredient to prevent CVD. RES has been reported to prevent AS progression in both mice and patients $[19,20]$ and the mechanisms refer to anti-oxidant, anti-platelet or anti-inflammatory[21]. RES protect AS in multiple ways, but the exact mechanism still unclarified and under discussion. It has been reported that RES regulates the immune response of CD4 ${ }^{+} \mathrm{T}$ cells by metabolic reprogramming, and inhibits $\mathrm{CD} 4^{+} \mathrm{T}$ cells activation by enhancing the expression of SIRT1[22, 23]. RES regulates $C D 4^{+} T$ cells activation via multiple mechanisms and regulates $C D 4^{+} T$ cells mediated inflammation. Moreover, RES has been reported as epigenetically active agents which function in regulating DNA methyltransferases (Dnmt) expression[24, 25]. DNA methylation is one of the best characterized epigenetic modifications and was mediated by Dnmt including Dnmt1, Dnmt3a and Dnmt3b[26]. Abnormal expression of Dnmt related to the dysfunctional cellular activities[27], and the changed expression of Dnmt is a potential mechanism for regulating $\mathrm{CD} 4^{+} \mathrm{T}$ cells activities. But whether RES influence $C D 4^{+} T$ cells by Dnmt regulating remains unknown.

This research aimed to investigated whether RES ameliorates AS induced by HFD and LPS in ApoE ${ }^{-/-}$ mice through regulates the activation of $\mathrm{CD}^{+}{ }^{+}$cells, as well as further detect the expression of Dnmt in $\mathrm{CD} 4^{+} \mathrm{T}$ cells.

\section{Materials And Methods}

\section{Animals}

Male $\mathrm{ApoE}^{-/-}$mice of 7 weeks old were purchased from Beijing Vital River Laboratory Animal Technology Co., Ltd. [certificate number: 11400700352760 , permit number: SCXK (JING) 2016-0006]. All mice were housed and bred under specific pathogen-free (SPF) conditions of Nanjing University of Chinese Medicine Experimental Animal Center [permit number: SYXK (SU) 2014-0001]. All animal studies were approved by Nanjing University of Chinese Medicine Experimental Animal Center and were performed in strict accordance with "Principles for Use of Animals" and "Guide for the Care and Use of Laboratory Animals" of the U.S. National Institutes of Health.

\section{Animals treatment}

Mice were departed into four groups as control, model (HFD + LPS), simvastatin and RES. Mice in control group were fed with normal diet, and HFD ( $1.25 \%$ cholesterol and $20 \%$ lard) were provided for twenty weeks to induce an advanced AS in mice of other groups. Besides, mice except for control group were attacked with $7.5 \mu \mathrm{g} / \mathrm{mice}$ of LPS (Sigma, L2880, 055:B5) i.p. once a week for five times from the 10th week. $3.3 \mathrm{mg} / \mathrm{kg}(\mathrm{BW}) /$ day of simvastatin (Merck Sharp \& Dohme Ltd) and $5 \mathrm{mg} / \mathrm{kg}$ (BW)/day of RES 
dispersed in $5 \%$ sodium carboxymethyl cellulose solution were intragastric administrated daily, and mice in control group received same amount of $5 \%$ sodium carboxymethyl cellulose solution. RES (purity $\geq$ 98\%) was purchased from Shanghai yuanye Bio-Technology Co., Ltd (CAS: 501-36-0).

\section{Serum lipids analysis}

Peripheral blood of mice were collected from the posterior orbital venous plexus. The blood was centrifuged for $10 \mathrm{~min}$ under the rotate speed of $3000 \mathrm{rpm}$ and the serum was collected for the analysis of serum lipids. The detection is performed according to the specification of enzymatic biochemical kits (Nanjing Jiancheng) via microplate reader (TECAN): Total Cholesterol Assay kit (Cat A111-1), Triacylglycerol Assay kit (Cat A110-1), Low Density Lipoprotein Cholesterol Assay kit (Cat A113-1), and High Density Lipoprotein Cholesterol Assay kit (Cat A112-1). The level of non-HDL-C was calculated by HDL-C subtracted from TC content.

\section{H\&E staining of coronary artery}

The hearts were fixed with $4 \%$ paraformaldehyde (PFA) and then embedded in paraffin. Further, they were sliced latitudinally, stained by hematoxylin-eosin (H\&E), and finally shot by a digital microscope (magnification: $\times 400$ ).

\section{Atherosclerotic plaque staining and analysis}

Aortas were separated from the aortic root to the left and right common iliac artery and the redundant tissue outside the aortas was removed carefully under the microscope. Then the aortas were cut off vertically by microscopic scissors and were stapled on the black foam plate. Oil red $\mathrm{O}$ was used for aortas staining after 12 hours fixation by $4 \%$ PFA and then $75 \%$ ethanol was used to differentiate normal tissue into creamy white. After thorough rinsing, the area of the atherosclerotic plaque was measured by MapInfo7.0 (USA, https://www.mapinfo.com).

\section{Cells assay}

$\mathrm{CD} 4^{+} \mathrm{T}$ cells were sorted from the spleen of C57BL/ 6 mice according to the operating steps of Dynabeads Untouched Mouse CD4 Cells (Invitrogen, 11416D) and then adjusted to the density of $1 \times 10^{6}$ cells/mL. Except for the control group, cells were stimulated by $1 \mu \mathrm{g} / \mathrm{mL}$ anti-CD3 (BioLegend, 100202) and $1 \mu \mathrm{g} / \mathrm{mL}$ anti-CD28 (Biolegend, 102102), and $0.1 \mu \mathrm{g} / \mathrm{mL}$ LPS were used to mimic an inflammatory environment for 24 hours in 24-wells dishes. 20, 40, $80 \mu \mathrm{M}$ of RES were added into cells and $1 \mu \mathrm{M}$ 5-Aza (MCE, Lot\#28452) was pretreated for 36 hours before the adding of LPS and RES in experiments necessary. CD4 $4^{+} \mathrm{T}$ cells were cultured in the cell incubator under the temperature of $37^{\circ} \mathrm{C}$ and $5 \% \mathrm{CO}_{2}$ and cultured by RPMI 1640 with 10\% fetal calf serum (Gibco, New Zealand, 10091148) and 1\% penicillin and streptomycin.

\section{Flow cytometry}

For flow cytometry, fresh blood was collected in anticoagulant tubes (BD, 8215736) and peripheral blood mononuclear cells (PBMC) were obtained by lymphocyte isolate medium (KeyGEN BioTECH, kga831). 
Cells were washed and treated with the Fixation/Permeabilization Solution (BD) for Ki67 detection, incubated with flow cytometry antibodies (BD Pharmingen), and resuspended in phosphate-buffered saline (PBS) with $1 \%$ bovine serum albumin (BSA). Then cells were determined with BD FACS Calibur Flow Cytometer. Antibody collocations were as follows:

i. $C D 4^{+}$CD $25^{+}$T cells: FITC Anti-Mouse CD4 (eBioscience, clone: RM4-4), APC Anti-Mouse CD25 (eBioscience, clone: PC61.5);

ii. $C D 4^{+}$CD 44 ${ }^{+}$T cells: FITC Anti-Mouse CD4 (eBioscience, clone: RM4-4), PerCP Anti-Mouse CD44 (BioLegend, clone: IM7);

iii. CD4 ${ }^{+} \mathrm{CD} 62 \mathrm{~L}^{+} \mathrm{T}$ cells: FITC Anti-Mouse CD4 (eBioscience, clone: RM4-4); PE Anti-Mouse CD62L (BD, clone: MEL-14);

iv. $\mathrm{CD}^{+} \mathrm{Ki}^{+}{ }^{+} \mathrm{T}$ cells: PE Anti-Mouse CD4 (BD, clone: RM4-5); FITC Anti-Mouse Ki67 (BioLegend, clone: 16A8).

\section{ELISA analysis}

The supernatant from CD4 ${ }^{+} T$ cells cultured above was subjected to detect the concentration of IL-2, IL-6, IL-10 and TGF- $\beta 1$ using ELISA. The assay was conducted according to the procedures recommended in the manufacturer's instructions of IL-2 (EK202HS-96), IL-6 (EK2061/2), IL-10 (EK210/3-96), TGF- $\beta 1$ (EK2812/2) ELISA kits. All these kits were obtained from Multisciences (Lianke) BioTECH.

\section{Quantitative real-time PCR (qRT-PCR)}

TRIzol Reagent (Invitrogen) was used to extract total RNA from spleens or aortas. $100 \mathrm{ng} / 10 \mu \mathrm{L}$ of spleen or aorta RNA were quantified with NanoDrop One (Thermo Scientific) and 5X All-In-One RT MasterMix (abm) was used for reverse transcription in Veriti 96-Well Thermal Cycler (Applied Biosystems). 7500 Real-Time PCR (Applied Biosystems) was used for qRT-PCR using specific primers (synthesized by Sangon Biotech) and Eva Green 2X qPCR Master Mix-Low ROX (abm). Reverse transcription and amplification conditions followed the reagent instructions. Data were analyzed via the $2^{-\Delta \Delta \mathrm{Ct}}$ method normalized to $\beta$-Actin. Sequences of primers were used as follows from $5^{\prime}$ to $3^{\prime}$ extremity:

i. ß-Actin: GGCTGTATTCCCCTCCATCG (F); CCAGTTGGTAACAATGCCATGT (R);

ii. Dnmt1: ATCCTGTGAAAGAGAACCCTGT (F); CCGATGCGATAGGGCTCTG (R);

iii. Dnmt3b: AGCGGGTATGAGGAGTGCAT (F); GGGAGCATCCTTCGTGTCTG (R)

\section{GGGAGCATCCTTCGTGTCTG (R)}

\section{Western blotting (WB) analysis}

Total protein was extracted from spleen or aorta by High Efficiency RIPA Lysis Buffer (KeyGEN BioTECH) and quantified by BCA protein concentration assay kit (Beyotime Biotechnology). Protein loading buffer 
(Beyotime Biotechnology) was added into protein and boiled for 5 minutes for protein degeneration. $30 \mu \mathrm{g}$ of protein was loaded in $8 \%$ SDS-PAGE gel and transferred onto polyvinylidene fluoride (PVDF) membranes (Merck Millipore). Skim milk in TBST (TBS containing $0.1 \%$ Tween 20) was used as a blocking agent before antibody incubation. PVDF membranes were incubated with rabbit antibodies against Dnmt3b (Cell Signaling Technology) and GAPDH (Abways), mice antibody Dnmt1 (Abcam). Goat anti-rabbit IgG and goat anti-mice with HRP (Proteintech) were chosen as the secondary antibody. The imaging was performed in Gel Doc XR Biorad (Bio-Rad) using Chemiluminescent HRP Substrate (Merck Millipore). Data was analyzed with Image Lab 4.0 (Bio-Rad). Gray values of blot areas were measured, and the relative expression amount of the protein samples was calculated by the method of the target protein gray value/internal reference GAPDH gray value.

\section{Statistical analysis}

Data are presented as the mean \pm standard derivation (SD) and were analyzed with Prism 5.02 software (GraphPad). Statistical analysis was performed using the unpaired Student's t-test to test the mean of two groups, and one-way analysis of variance (ANOVA) was applied for comparisons between multiple experimental groups. A value of $\mathrm{P}<0.05$ were considered statistically significant difference.

\section{Results}

\section{RES regulated serum lipids and ameliorated AS in $\mathrm{ApoE}^{-/-}$ mice}

The level of serum lipids including TC, TG, LDL-C, and HDL-C in the 0th, 10th and 20th weeks of the experiment were detected while the content of non-HDL-C was calculated (Fig. 1A-C). The level of TC, TG, LDL-C, and non-HDL-C significantly increased after ten weeks of HFD. At the 20th week, compared to mice of the control group, the concentration of TC, TG, LDL-C as well as non-HDL-C all increased while HDL-C level decreased. Compared to mice of HFD + LPS group, $5 \mathrm{mg} / \mathrm{kg}(\mathrm{BW}) /$ day of RES decreased content of TC, TG and non-HDL-C at 10th week, and decreased content of TC, TG, LDL-C and non-HDL-C, meanwhile increased content of HDL-C at 20th week, suggesting that the ability of RES on regulating lipids in atherosclerotic mice induced by HFD and LPS will increase with prolonged use.

Both HFD and LPS are harmful to the mammal blood vessels. After twenty weeks of HFD together with five times of LPS injection, the coronary wall hypertrophy was observed (Fig. 1D), and large area of atherosclerotic plaque was detected on aortas (Fig. 1E-F). Simvastatin or RES treatment ameliorated the pathological change of coronary wall slightly. In addition, simvastatin or RES treatment decreased the infiltrated lesion of the aorta and the plaque area ratio significantly. These results indicated that RES treatment can inhibit the progression of AS.

Serum of mice was collected at 0 th, 10 th and 20th respectively and diluted by a quarter in saline and the lipids were detected according to the operating instruction of the kits. (A) The level of total cholesterol (TC), triglyceride (TG), low density lipoprotein cholesterol (LDL-C), high density lipoprotein cholesterol $(H D L-C)$, and non-HDL-C of serum in the 0th week $(n=8)$. (B) The level of TC, TG, LDL-C, HDL-C, and non- 
HDL-C in the 10th week ( $n=8)$. (C) The level of TC, TG, LDL-C, HDL-C, and non-HDL-C in the 20th week ( $\mathrm{n}$ = 8). (D) Mice were killed at the end of the 20th week and the hearts were preserved. The pathologic condition of the coronary artery was analyzed by H\&E. (E) The aortas were separated from the aortic arch to the left and right common iliac artery and were stained by Oil Red O. (F) The areas of aortic plaque were measured by Maplnfo $7.0(n=5)$.

Data are represented with mean $\pm S D$, \#P $<0.05$, \#\#P < 0.01, \#\#\#P<0.001 versus the control group; *P < 0.05 , **P $<0.01$ versus the HFD + LPS group.

\section{RES inhibited the activation of $\mathrm{CD}^{+} \mathrm{T}$ cells in atherosclerotic mice}

In order to observe the effects of RES on $C D 4^{+} \mathrm{T}$ cells in atherosclerotic mice, the frequency of CD $4^{+} \mathrm{T}$ cells in peripheral blood mononuclear cells (PBMC) was detected. It was observed that the frequency of $\mathrm{CD}^{+} \mathrm{T}$ cells was increased with combinational stimulation of HFD and LPS while RES decreased the ratio of $\mathrm{CD}^{+} \mathrm{T}$ cells in PBMC (Fig. 2A-B), which suggested RES improved the inflammatory status in AS. CD25, CD44 and CD62L were detected to analyze the activation of CD4 ${ }^{+}$T cells (Fig. 2C-D). It was found that HFD and LPS injection increased the expression of CD25 and CD44, and decreased CD62L expression in $\mathrm{CD}^{+} \mathrm{T}$ cells in peripheral blood. Intragastric administration of RES decreased CD25 and CD44 expression, but CD62L expression was not changed. The expression change of activation markers suggested that RES can reduce the expression of CD25 and CD44, but does not affect CD62L expression in AS mice with combinational stimulation of HFD and LPS.

Peripheral blood of mice was collected at the end of the 20th week and lymphocyte isolate medium was used to obtain peripheral blood mononuclear cells (PBMC). (A-B) CD4 FITC antibody was used and the frequency of $\mathrm{CD}^{+} \mathrm{T}$ cells in PBMC was detected by flow cytometry ( $\left.\mathrm{n}=4\right)$. (C-D) CD4 FITC, CD25 APC, CD44 PerCP and CD62L PE antibody were used to stain the cells and the frequency of CD25 ${ }^{+} \mathrm{CD}_{4} 4^{+}$and $\mathrm{CD} 2 \mathrm{~L}^{+}$cells in $\mathrm{CD}^{+}$T cells were analyzed by flow cytometry $(\mathrm{n}=4)$.

Data are represented with mean $\pm S D$, \#P<0.05, \#\#P<0.01, \#\#\#P<0.001 versus the control group; *P < $0.05, * * P<0.01$ versus the HFD + LPS group.

\section{RES inhibited the activation of $\mathrm{CD} 4^{+} \mathrm{T}$ cells in vitro}

We further studied the effects of RES on the activation of CD4 ${ }^{+} \mathrm{T}$ cells in vitro. To access the proliferation of $\mathrm{CD}^{+} \mathrm{T}$ cells, Ki67, which is specifically expressed in proliferating cells, was detected (Fig. 3A-B). TCR and LPS treatment increased the expression of Ki67 in CD $4^{+} \mathrm{T}$ cells while $20 \mu \mathrm{M}$ and $40 \mu \mathrm{M}$ of RES decreased Ki67 expression under TCR and LPS treatment. Surprisingly, increased Ki67 expression was detected under $80 \mu \mathrm{M}$ of RES treatment.

In addition, TCR and LPS stimulation significantly increased the expression of CD25 and CD44 and decreased CD62L expression in $\mathrm{CD}^{+} \mathrm{T}$ cells. 20, 40, and $80 \mu \mathrm{M}$ of RES decreased the expression of CD25 
in $\mathrm{CD}^{+} \mathrm{T}$ cells while 20 and $40 \mu \mathrm{M}$ of RES decreased CD44 expression, the influence of $80 \mu \mathrm{M}$ of RES on CD44 expression was not detected. It was notably that 20 and $40 \mu \mathrm{M}$ of RES have no influence on CD62L expression, but $80 \mu \mathrm{M}$ of RES unexpectedly decreased CD62L (Fig. 3C-D).

Cytokines secreted by CD $4^{+}$T cells were detected (Fig. 3E). $80 \mu \mathrm{M}$ of RES increased IL-6, IL-10 and TGF$\beta 1$ level in supernatant but had no effect on IL-2 level. $40 \mu \mathrm{M}$ of RES increased IL-2 and TGF- $\beta 1$ but did not influence IL- 6 and IL-10 secretion. $20 \mu \mathrm{M}$ of RES increased the TGF- $\beta 1$ level but did not change the secretion of IL-2, IL-6, and IL-10. RES was not powerful in regulating IL-2, IL-6, and IL-10 secretion, but promotes TGF- $\beta 1$ secretion. In summary, different concentrations of RES has different effects on the expression of markers of proliferation and activation in $\mathrm{CD} 4^{+} \mathrm{T}$ cells as well as cytokines secretion.

CD4 ${ }^{+} \mathrm{T}$ cells were stimulated by $1 \mu \mathrm{g} / \mathrm{mL}$ anti-CD3 and $1 \mu \mathrm{g} / \mathrm{mL}$ anti-CD28 and cultured in a cell incubator. $0.1 \mu \mathrm{g} / \mathrm{mL}$ LPS and $20,40,80 \mu \mathrm{M}$ of RES were added and cells were collected 24 hours later.

(A-B) The expression of proliferation marker, Ki67 was observed by flow cytometry $(n=4)$. (C-D) The expression of activation markers including CD25, CD44, and CD62L of CD $4^{+} T$ cells were observed by flow cytometry $(n=4)$. (E) The cytokines of IL-2, IL-6, IL-10, and TGF- $\beta 1$ in the culture supernatant were detected by ELISA $(n=5)$.

Data are represented with mean $\pm S D, \# P<0.05$, \#\#P<0.01, \#\#\#P<0.001 versus the control group; $* P<$ 0.05 , $* * P<0.01, * \star * P<0.01$ versus the TCR + LPS group.

\section{RES affected CD4 ${ }^{+} T$ cells by inhibiting Dnmt1 and Dnmt3b}

To observe the expression of Dnmt in $\mathrm{CD}^{+} \mathrm{T}$ cells, the level of mRNA and protein of Dnmt were detected (Fig. 4A-C). mRNA expression of Dnmt1 and Dnmt3b were increased in CD $4^{+} \mathrm{T}$ cells treated by $\mathrm{TCR}$ and LPS, and protein expression of Dnmt1 was also increased. $20 \mu \mathrm{M}$ of RES decreased the expression of Dnmt1 and Dnmt3b in both mRNA and protein levels. 40 and $80 \mu \mathrm{M}$ of RES decreased protein expression of Dnmt1 and decreased mRNA and protein expression of Dnmt3b. In order to confirm whether these expression changes of Dnmt affect the activities of CD4 ${ }^{+} \mathrm{T}$ cells, 5-Aza, an inhibitor for Dnmt was used. It was verified that 5-Aza significantly inhibited the expression of Dnmt3b in both mRNA and protein levels, but Dnmt1 is not influenced by 5-Aza (Fig. 4D-F). $40 \mu \mathrm{M}$ of RES was similar to 5-Aza in inhibiting Dnmt3b and besides, $40 \mu \mathrm{M}$ of RES decreased Dnmt1 protein expression, but mRNA expression of Dnmt1 has not been detected. Both 5-Aza and $40 \mu \mathrm{M}$ of RES inhibited the expression of Ki67 (Fig. 4G-H), CD25 and CD44 (Fig. 4I-J). In addition, the combination of 5-Aza and $40 \mu \mathrm{M}$ of RES reduced Dnmt1 protein level and Dnmt3b mRNA and protein level, and decreased the expression of Ki67, CD25, and CD44.

$\mathrm{CD}^{+} \mathrm{T}$ cells were stimulated by $1 \mu \mathrm{g} / \mathrm{mL}$ anti-CD3 and $1 \mu \mathrm{g} / \mathrm{mL}$ anti-CD28 and cultured in a cell incubator. $0.1 \mu \mathrm{g} / \mathrm{mL}$ LPS and $20,40,80 \mu \mathrm{M}$ of RES were added and cells were collected 24 hours later. (A) mRNA level of Dnmt in CD $4^{+}$T cells detected by qRT-PCR $(n=4)$. $(B-C)$ The protein level of Dnmt in CD4 ${ }^{+} T$ cells detected by WB $(n=4)$. 
5-Aza were pretreated for 36 hours, and cells were collected after the treatment of LPS and $40 \mu \mathrm{M}$ of RES.

(D) mRNA level of Dnmt in CD4+ $T$ cells $(n=4)$. $(E-F)$ The protein level of Dnmt in CD4 ${ }^{+} T$ cells $(n=4)$. (GH) The expression of proliferation marker, Ki67 was observed by flow cytometry $(n=4)$. $(I-J)$ The expression of activation markers including $\mathrm{CD} 25$ and $\mathrm{CD} 44$ of $\mathrm{CD} 4^{+} \mathrm{T}$ cells were observed by flow cytometry $(n=4)$.

Data are represented with mean $\pm S D, \# P<0.05$, \#\#P<0.01, \#\#\#P<0.001 versus the control group; *P $<$ $0.05, \star * P<0.01, * \star \star P<0.001$ versus the TCR + LPS group.

\section{Discussion}

In our research, we demonstrated that RES effectively ameliorated AS induced by HFD companied with LPS in $\mathrm{ApoE}^{-/-}$mice. In addition, our results indicated that RES treatment significantly inhibited the accumulation of lipids on vessel wall, inhibited the proliferation and activation of $\mathrm{CD} 4^{+} \mathrm{T}$ cells, regulated the secretion of cytokines and decreased the expression of Dnmt. Our research clarified the mechanism of RES in preventing AS through regulating activation of $\mathrm{CD} 4^{+} \mathrm{T}$ cells and Dnmt expression.

AS is a chronic inflammatory disease[1]. High level of serum lipids and the inflammatory status are risk factors of AS[2, 28]. Feeding ApoE ${ }^{-/-}$mice with HFD can induce AS and LPS injection can accelerate the progression of disease[29]. In our study, HFD companied with LPS induced dysfunction of serum lipids and formation of atherosclerotic plaque. Administration of RES counteracts thickened coronary artery, decreased the accumulation of lipids on the aortic wall, and regulated the level of serum lipids, indicated the positive function of RES on HFD and LPS induced $\mathrm{AS}$ in $\mathrm{ApoE}^{-/-}$mice.

Dyslipidemia is a recognized risk factor of AS. In our study, RES decreased the high level of TC and TG in 10th week of the experiment and inhibited the dysfunction of TC, TG, LDL-C as well as HDL-C in 20th week. RES has been widely reported to regulate serum lipids[30, 31], promote the degradation of oxLDL[32], suppress adipocyte differentiation and TC accumulation, and stimulate lipolysis. RES powerfully regulated the serum lipids and our result further verified this efficiency and hinted that RES play this function in a long time.

Rather than regulated serum lipids, RES attenuated Trimethylamine-N-Oxide (TMAO)-induced AS in $\mathrm{ApoE}^{-/-}$mice[33], ameliorated HFD induced AS in $\mathrm{LDLR}^{-/-}$mice[34], countered systemic lupus erythematosus-associated AS[35] and alleviated AS in atherosclerotic mice whose left carotid artery was partial ligated[36]. Our result is consistent with previous studies that RES possess beneficial effects on AS and the influences of RES on AS induced by HFD and LPS was firstly observed in our research. LPS is an inflammatory risk factor. The infection of bacteria like Mycobacterium tuberculosis can increases the level of LPS[37]. Elevated LPS is easily to induce a low-grade inflammation state, which is another risk factor for AS in addition to a high level of serum lipids[38]. 
RES ameliorates the symptoms of AS through multiple mechanisms. RES regulates the production of vasodilator and vasoconstrictor, inhibits the generation of oxidative stress/reactive oxygen species and ameliorates inflammation[39]. But the precise mechanism of how RES alleviate AS still complex and incompletely clarified. Our study verified a mechanism of RES in ameliorating HFD and LPS induced AS by regulating Dnmt expression, inhibiting the activation of $\mathrm{CD} 4^{+} \mathrm{T}$ cells.

$\mathrm{CD}^{+} \mathrm{T}$ cells are the most abundant $\mathrm{T}$ cells population in atherosclerotic plaque and play important roles throughout all stages of AS. CD62L is critical for migration of naïve $C D 4^{+} T$ cells into lymphoid tissue and highly expressed on naïve $\mathrm{CD} 4^{+} \mathrm{T}$ cells and downregulated upon the activation[40]. Besides, $\mathrm{CD} 4^{+} \mathrm{T}$ cells increase the expression of CD25 and CD44 after activation[41, 42, 43, 44].

Activated $\mathrm{CD} 4^{+} \mathrm{T}$ cells response to the antigen signal, secret inflammatory cytokines and began to proliferation. Increased and activated $\mathrm{CD} 4^{+} \mathrm{T}$ cells accelerate the progression of inflammation and induce the progression of AS[45]. RES inhibited the proliferation and activation of $\mathrm{CD} 4^{+} \mathrm{T}$ cells both in atherosclerotic mice and in cultured splenic $\mathrm{CD} 4^{+} \mathrm{T}$ cells in vitro, which remained us that RES ameliorated AS by inhibiting the proliferation and activation of $\mathrm{CD} 4^{+} \mathrm{T}$ cells.

$\mathrm{CD} 4^{+} \mathrm{T}$ cells are constituents of the adaptive immune response[46]. Activated $\mathrm{CD} 4^{+} \mathrm{T}$ cells secrete proinflammatory cytokines and inflammation mediated by activated $\mathrm{CD} 4^{+} \mathrm{T}$ cells plays an important role in the initiation and progression of AS[47]. RES decreased the secretion of IL-6, increased IL-10 and TGF$\beta 1$. IL- 6 contributes to host defense through the stimulation of acute phase responses, hematopoiesis, and immune reactions. Continual secretion of IL- 6 plays a pathological effect on chronic inflammation[48]. It has been reported that low content of IL-10-producing CD4 ${ }^{+} \mathrm{T}$ cells is a risk factor for progression of coronary AS[49] and evoking TGF- $\beta 1$-mediated anti-inflammatory response inhibited AS progression[50]. Besides, RES increased the secretion of IL-2 in CD $4^{+} \mathrm{T}$ cells. IL-2 is a proinflammatory cytokine and the level of IL-2 may be close correlated with the development and progression of CVD[51, 52]. But IL-2 can induce the development of Tregs, which protect against AS[53]. The effects of increased IL-2 in AS still under discussion. RES promoted lymphocyte proliferation and IL-2 production[54] and we confirmed the same function of RES on $\mathrm{CD} 4^{+} \mathrm{T}$ cells. RES inhibited the activation and proliferation of $\mathrm{CD} 4^{+} \mathrm{T}$ cells, regulated the secretion of cytokines. We concluded that RES restrained the immune response of $\mathrm{CD} 4^{+} \mathrm{T}$ cells.

According to our results, the effects of different concentrations of RES on $\mathrm{CD} 4^{+} \mathrm{T}$ cells are inconsistent. Marco Craveiro et al. reported that 20 and $100 \mu \mathrm{M}$ of RES possess different influences on human CD4 ${ }^{+} \mathrm{T}$ cells stimulated by TCR[55]. Both 20 and $100 \mu \mathrm{M}$ of RES decreased the expression of CD25 and CD71 but did not affect CD69 expression. In addition, $20 \mu \mathrm{M}$ of RES inhibited the proliferation of human CD $4^{+} \mathrm{T}$ cells while $100 \mu \mathrm{M}$ of RES had no effects. These results indicated that the different concentration of RES can cause different or even opposite effects on activation and proliferation of $\mathrm{CD} 4^{+} \mathrm{T}$ cells, which remained us that the dose of RES in application should pay enough attention. 
Dnmt1 maintain the methylation and Dnmt3b mediate the de novo methylation. Aberrant or abnormal expression of Dnmt is associated with a variety of human diseases including AS. Therefore, Dnmt are promising therapeutic epigenetic targets as specific inhibitors might regulate the expression of Dnmt and stop or even reverse aberrant cellular processes $[56,57]$. RES has been described as a regulator of Dnmt expression and majority of the research concluded that RES function as inhibitors of Dnmt in many kind of cells[58]. In our research, RES inhibited the increased Dnmt1 and Dnmt3b induced by anti-CD3/CD28 companied with LPS in $\mathrm{CD} 4^{+} \mathrm{T}$ cells, which is consistent with the research that RES inhibited Dnmt expression.

Inhibited expression of Dnmt induced the regulation of cellular activities and we investigated in $\mathrm{CD} 4^{+} \mathrm{T}$ cells that decreased expression of Dnmt1 and Dnmt3b induced the inhibition of proliferation and activation, suggested that RES induced inhibition of proliferation and activation of $\mathrm{CD}^{+} \mathrm{T}$ cells is partly through the inhibition of Dnmt1 and Dnmt3b.

There are some new sights in this research that our study suggested RES ameliorated AS induced by HFD together with LPS in $\mathrm{ApoE}^{-/-}$mice. In addition, RES function like an inhibitor of Dnmt1 and Dnmt3b in $\mathrm{CD} 4^{+} \mathrm{T}$ cells. Finally, RES inhibited the proliferation and activation as well as regulated the secretion of cytokines in $\mathrm{CD}^{+} \mathrm{T}$ cells. This research clarified much about the mechanism of RES in AS treatment.

Limitations also existed in this research. Although RES can inhibit the expression of Dnmt1 and Dnmt3b in $\mathrm{CD}^{+} \mathrm{T}$ cells, whether there existed dysfunctional methylation of DNA calls for further examined. Other probable mechanisms may exist besides the Dnmt 1 and Dnmt3b inhibition that underlies the RESmediated inhibition of the proliferation and activation of $\mathrm{CD} 4^{+} \mathrm{T}$ cells.

\section{Conclusion}

In summary, our research demonstrated that RES administration ameliorated AS induced by HFD companied with LPS in $\mathrm{ApoE}^{-/-}$mice by inhibiting the activation of $\mathrm{CD} 4^{+} \mathrm{T}$ cells, which is achieved by the inhibition of Dnmt1 and Dnmt3b. This work clarified a new mechanism of RES attenuating AS and provided more evidences for the application of RES.

\section{Abbreviations}

AS, atherosclerosis;

CD62L, L-selectin;

Cont, control;

CVD, cardiovascular disease;

Dnmt, DNA methyltransferase; 
HDL-C, high density lipoprotein cholesterol;

HFD, high-fat diet;

IL, interleukin;

LDL-C, low density lipoprotein cholesterol;

PBMC, peripheral blood mononuclear cells;

PFA, paraformaldehyde;

RES, resveratrol;

Simva, simvastatin;

TC, total cholesterol;

TG, triglyceride;

TGF- $\beta 1$, transforming growth factor- $\beta 1$;

5-Aza, 5-Azacytidine.

\section{Declarations}

\section{Ethics approval}

All animal studies were approved by Nanjing University of Chinese Medicine Experimental Animal Center and were performed in strict accordance with "Principles for Use of Animals" and "Guide for the Care and Use of Laboratory Animals" of the U.S. National Institutes of Health. All killings were performed under sodium pentobarbital anesthesia, and efforts were taken to minimize animal suffering.

\section{Consent for publication}

Not applicable.

\section{Competing interests}

The authors declare that they have no competing interests.

\section{Funding}

This work was supported by the National Natural Science Foundation of China (Grant No.81973823, No.81573929, No.81373232), the Open Project Program of Jiangsu Key Laboratory for Pharmacology and Safety Evaluation of Chinese Materia Medica (No. JKLPSE201821), the Project of the Priority 
Academic Program Development of Jiangsu Higher Education Institutions (PAPD), and National Major Science and Technology Special Projects for "Major New Drugs Innovation and Development" (No. 2017ZX09309022).

\section{Author information}

Liyu Zhou and Jun Long contributed equally to this work.

\section{Affiliations}

Jiangsu Key Laboratory for Pharmacology and Safety Evaluation of Chinese Materia Medica, School of Pharmacy, Nanjing University of Chinese Medicine, Xianlin Dadao 138, Nanjing 210023, China.

Liyu Zhou, Jun Long, Yuting Sun, Weikai Chen \& Dongping Yuan

Department of Clinical Pharmacology Laboratory, Nanjing First Hospital, Nanjing Medical University, Nanjing, 210006 China.

Runze Qiu

\section{contributions}

WKC and RZQ are involved in the bench work. LYZ and YTS performed the experiments and data analysis. LYZ, JL and DPY designed and organized the study, interpreted the results, and the prepared the manuscript. All authors have read and approved the final manuscript.

\section{Corresponding author}

Correspondence to Dongping Yuan

\section{Availability of data and materials}

The datasets used and/or analysed during the current study are available from the corresponding author on reasonable request.

\section{Acknowledgements}

Not applicable.

\section{References}

1. Libby P, Ridker PM, Hansson GK. Progress and challenges in translating the biology of atherosclerosis. Nature. 2011;473:317-25. 
2. Hansson GK, Hermansson A. The immune system in atherosclerosis. Nat Immunol. 2011;12:204-12.

3. Soliman GA. Dietary Fiber, Atherosclerosis, and Cardiovascular Disease. Nutrients. 2019;11:1155.

4. Lim GB. Dyslipidaemia: ANGPTL3: a therapeutic target for atherosclerosis. Nat Rev Cardiol. 2017;14:381.

5. Raggi P, Genest J, Giles JT, Rayner KJ, Dwivedi G, Beanlands RS, Gupta M. Role of inflammation in the pathogenesis of atherosclerosis and therapeutic interventions. Atherosclerosis. 2018;276:98-108.

6. Hansson GK, Hermansson A. The immune system in atherosclerosis. Nat Immunol. 2011;12:204-12.

7. Tabas I, Lichtman AH. Monocyte-Macrophages and T Cells in Atherosclerosis. Immunity. 2017;47:621-634.

8. Li N. CD4+ T cells in atherosclerosis: regulation by platelets. Thromb Haemost. 2013;109:980-90.

9. Dumitru C, Kabat AM, Maloy KJ. Metabolic Adaptations of CD4+ T Cells in Inflammatory Disease. Front Immunol. 2018;9:540.

10. Tse K, Tse H, Sidney J, Sette A, Ley K. T cells in atherosclerosis. Int Immunol. 2013;25:615-22.

11. Sécca C, Faget DV, Hanschke SC, Carneiro MS, Bonamino MH, de-Araujo-Souza PS, Viola JP. IRF2BP2 transcriptional repressor restrains naive CD4 T cell activation and clonal expansion induced by TCR triggering. J Leukoc Biol. 2016;100:1081-1091.

12. Gregorczyk I, Maślanka T. Effect of selected non-steroidal anti-inflammatory drugs on activationinduced CD25 expression on murine CD4+ and CD8+ T cells: an in vitro study. Cent Eur J Immunol. 2019;44:109-118.

13. Brockmann L, Soukou S, Steglich B, Czarnewski P, Zhao L, Wende S, Bedke T, Ergen C, Manthey C, Agalioti T, Geffken M, Seiz O, Parigi SM, Sorini C, Geginat J, Fujio K, Jacobs T, Roesch T, Izbicki JR, Lohse AW, Flavell RA, Krebs C, Gustafsson JA, Antonson P, Roncarolo MG, Villablanca EJ, Gagliani N, Huber S. Molecular and functional heterogeneity of IL-10-producing CD4+ T cells. Nat Commun. 2018;9:5457.

14. Carabelli J, Prato CA, Sanmarco LM, Aoki MP, Campetella O, Tribulatti MV. Interleukin-6 signalling mediates Galectin-8 co-stimulatory activity of antigen-specific CD4 T-cell response. Immunology. 2018;155:379-386.

15. Robinson RT, Gorham JD. TGF-beta 1 regulates antigen-specific CD4+ T cell responses in the periphery. J Immunol. 2007;179:71-79.

16. Lü SL, Dang GH, Deng JC, Liu HY, Liu B, Yang J, Ma XL, Miao YT, Jiang CT, Xu QB, Wang X, Feng J. Shikonin attenuates hyperhomocysteinemia-induced CD4+ T cell inflammatory activation and atherosclerosis in ApoE-/- mice by metabolic suppression. Acta Pharmacol Sin. 2020;41:47-55.

17. Malaguarnera L. Influence of Resveratrol on the Immune Response. Nutrients. 2019;11:946.

18. Silva RCD, Teixeira JA, Nunes WDG, Zangaro GAC, Pivatto M, Caires FJ, lonashiro M. Resveratrol: A thermoanalytical study. Food Chem. 2017;237:561-565.

19. Berbée JF, Wong MC, Wang Y, van der Hoorn JW, Khedoe PP, van Klinken JB, Mol IM, Hiemstra PS, Tsikas D, Romijn JA, Havekes LM, Princen HM, Rensen PC. Resveratrol protects against 
atherosclerosis, but does not add to the antiatherogenic effect of atorvastatin, in APOE*3Leiden.CETP mice. J Nutr Biochem. 2013;24:1423-30.

20. Tomé-Carneiro J, Gonzálvez M, Larrosa M, Yáñez-Gascón MJ, García-Almagro FJ, Ruiz-Ros JA, Tomás-Barberán FA, García-Conesa MT, Espín JC. Grape resveratrol increases serum adiponectin and downregulates inflammatory genes in peripheral blood mononuclear cells: a triple-blind, placebocontrolled, one-year clinical trial in patients with stable coronary artery disease. Cardiovasc Drugs Ther. 2013;27:37-48.

21. Wiciński M, Socha M, Walczak M, Wódkiewicz E, Malinowski B, Rewerski S, Górski K, Pawlak-Osińska K. Beneficial Effects of Resveratrol Administration-Focus on Potential Biochemical Mechanisms in Cardiovascular Conditions. Nutrients. 2018;10:1813.

22. Craveiro M, Cretenet G, Mongellaz C, Matias MI, Caron O, de Lima MCP, Zimmermann VS, Solary E, Dardalhon V, Dulić V, Taylor N. Resveratrol stimulates the metabolic reprogramming of human CD4+ T cells to enhance effector function. Sci Signal. 2017;10:eaal3024.

23. Zou T, Yang Y, Xia F, Huang A, Gao X, Fang D, Xiong S, Zhang J. Resveratrol Inhibits CD4+ T cell activation by enhancing the expression and activity of Sirt1. PLoS One. 2013;8:e75139.

24. Maugeri A, Barchitta M, Mazzone MG, Giuliano F, Basile G, Agodi A. Resveratrol Modulates SIRT1 and DNMT Functions and Restores LINE-1 Methylation Levels in ARPE-19 Cells under Oxidative Stress and Inflammation. Int J Mol Sci. 2018;19:2118.

25. Aldawsari FS, Aguayo-Ortiz R, Kapilashrami K, Yoo J, Luo M, Medina-Franco JL, Velázquez-Martínez CA. Resveratrol-salicylate derivatives as selective DNMT3 inhibitors and anticancer agents. J Enzyme Inhib Med Chem. 2016;31:695-703.

26. Lyko F. The DNA methyltransferase family: a versatile toolkit for epigenetic regulation. Nat Rev Genet. 2018;19:81-92.

27. Lee DY, Chiu JJ. Atherosclerosis and flow: roles of epigenetic modulation in vascular endothelium. J Biomed Sci. 2019;26:56.

28. Libby P, Bornfeldt KE, Tall AR. Atherosclerosis: Successes, Surprises, and Future Challenges. Circ Res. 2016;118:531-4.

29. van Broekhoven A, Krijnen PAJ, Fuijkschot WW, Morrison MC, Zethof IPA, van Wieringen WN, Smulders YM, Niessen HWM, Vonk ABA. Short-term LPS induces aortic valve thickening in ApoE`3Leiden mice. Eur J Clin Invest. 2019;49:e13121.

30. Zhang HZ, Chen DW, He J, Zheng P, Yu J, Mao XB, Huang ZQ, Luo YH, Luo JQ, Yu B. Long-term dietary resveratrol supplementation decreased serum lipids levels, improved intramuscular fat content, and changed the expression of several lipid metabolism-related miRNAs and genes in growing-finishing pigs1. J Anim Sci. 2019;97:1745-1756.

31. Jeon SM, Lee SA, Choi MS. Antiobesity and vasoprotective effects of resveratrol in apoE-deficient mice. J Med Food. 2014;17:310-6.

32. Zhang Y, Cao X, Zhu W, Liu Z, Liu H, Zhou Y, Cao Y, Liu C, Xie Y. Resveratrol Enhances Autophagic Flux and Promotes Ox-LDL Degradation in HUVECs via Upregulation of SIRT1. Oxid Med Cell Longev. 
2016;2016:7589813.

33. Chen ML, Yi L, Zhang Y, Zhou X, Ran L, Yang J, Zhu JD, Zhang QY, Mi MT. Resveratrol Attenuates Trimethylamine-N-Oxide (TMAO)-Induced Atherosclerosis by Regulating TMAO Synthesis and Bile Acid Metabolism via Remodeling of the Gut Microbiota. mBio. 2016;7:e02210-15.

34. Chassot LN, Scolaro B, Roschel GG, Cogliati B, Cavalcanti MF, Abdalla DSP, Castro IA. Comparison between red wine and isolated trans-resveratrol on the prevention and regression of atherosclerosis in LDLr (-/-) mice. J Nutr Biochem. 2018;61:48-55.

35. Voloshyna I, Teboul I, Littlefield MJ, Siegart NM, Turi GK, Fazzari MJ, Carsons SE, DeLeon J, Reiss AB. Resveratrol counters systemic lupus erythematosus-associated atherogenicity by normalizing cholesterol efflux. Exp Biol Med (Maywood). 2016;241:1611-9.

36. Seo Y, Park J, Choi W, Ju Son D, Sung Kim Y, Kim MK, Yoon BE, Pyee J, Tae Hong J, Go YM, Park H. Antiatherogenic Effect of Resveratrol Attributed to Decreased Expression of ICAM-1 (Intercellular Adhesion Molecule-1). Arterioscler Thromb Vasc Biol. 2019;39:675-684.

37. Munford RS. Endotoxemia-menace, marker, or mistake? J Leukoc Biol. 2016;100:687-698.

38. Zhou Y, Chen R, Liu D, Wu C, Guo P, Lin W. Asperlin Inhibits LPS-Evoked Foam Cell Formation and Prevents Atherosclerosis in ApoE-/- Mice. Mar Drugs. 2017;15:358.

39. Fan E, Zhang L, Jiang S, Bai Y. Beneficial effects of resveratrol on atherosclerosis. J Med Food. 2008;11:610-4.

40. Foster JG, Carter E, Kilty I, MacKenzie AB, Ward SG. Mitochondrial superoxide generation enhances P2X7R-mediated loss of cell surface CD62L on naive human CD4+ T lymphocytes. J Immunol. 2013;190:1551-9.

41. Waters WR, Rahner TE, Palmer MV, Cheng D, Nonnecke BJ, Whipple DL. Expression of L-Selectin (CD62L), CD44, and CD25 on activated bovine T cells. Infect Immun. 2003;71:317-26.

42. Gerberick GF, Cruse LW, Miller CM, Sikorski EE, Ridder GM. Selective modulation of T cell memory markers CD62L and CD44 on murine draining lymph node cells following allergen and irritant treatment. Toxicol Appl Pharmacol. 1997;146:1-10.

43. Thaxton JE, Wallace C, Riesenberg B, Zhang Y, Paulos CM, Beeson CC, Liu B, Li Z. Modulation of Endoplasmic Reticulum Stress Controls CD4+ T-cell Activation and Antitumor Function. Cancer Immunol Res. 2017;5:666-675.

44. Lu X, Rudemiller NP, Wen Y, Ren J, Hammer GE, Griffiths R, Privratsky JR, Yang B, Sparks MA, Crowley SD. A20 in Myeloid Cells Protects Against Hypertension by Inhibiting Dendritic Cell-Mediated T-Cell Activation. Circ Res. 2019;125:1055-1066.

45. Lü SL, Dang GH, Deng JC, Liu HY, Liu B, Yang J, Ma XL, Miao YT, Jiang CT, Xu QB, Wang X, Feng J. Shikonin attenuates hyperhomocysteinemia-induced CD4+ T cell inflammatory activation and atherosclerosis in ApoE-/- mice by metabolic suppression. Acta Pharmacol Sin. 2020;41:47-55.

46. Kritikou E, van der Heijden T, Swart M, van Duijn J, Slütter B, Wezel A, Smeets HJ, Maffia P, Kuiper J, Bot I. Hypercholesterolemia Induces a Mast Cell-CD4+ T Cell Interaction in Atherosclerosis. J Immunol. 2019;202:1531-1539. d 
47. Lü S, Deng J, Liu H, Liu B, Yang J, Miao Y, Li J, Wang N, Jiang C, Xu Q, Wang X, Feng J. PKM2dependent metabolic reprogramming in $\mathrm{CD} 4+\mathrm{T}$ cells is crucial for hyperhomocysteinemiaaccelerated atherosclerosis. J Mol Med (Berl). 2018;96:585-600.

48. Tanaka T, Narazaki M, Kishimoto T. IL-6 in inflammation, immunity, and disease. Cold Spring Harb Perspect Biol. 2014;6:a016295.

49. Filatova AY, Pylaeva EA, Potekhina AV, Ruleva NY, Klesareva EA, Radyukhina NV, Masenko VP, Shchinova AM, Noeva EA, Provatorov SI, Afanas'eva OI, Aref'eva TI. Low Blood Content of IL-10Producing CD4+ T Cells as a Risk Factor for Progression of Coronary Atherosclerosis. Bull Exp Biol Med. 2019;166:330-333.

50. Terada K, Yamada H, Kikai M, Wakana N, Yamamoto K, Wada N, Motoyama S, Saburi M, Sugimoto T, Irie D, Kato T, Kawahito H, Kami D, Ogata T, Matoba S. Transplantation of periaortic adipose tissue inhibits atherosclerosis in apoE-/- mice by evoking TGF- $\beta 1$-mediated anti-inflammatory response in transplanted graft. Biochem Biophys Res Commun. 2018;501:145-151.

51. Ding R, Gao W, Ostrodci DH, He Z, Song Y, Ma L, Liang C, Wu Z. Effect of interleukin-2 level and genetic variants on coronary artery disease. Inflammation. 2013;361225-31.

52. Damluji AA, Ramireddy A, Al-Damluji MS, Marzouka GR, Otalvaro L, Viles-Gonzalez JF, Dong C, Alfonso CE, Hendel RC, Cohen MG, Moscucci M, Bishopric NH, Myerburg RJ. Association between anti-human heat shock protein-60 and interleukin-2 with coronary artery calcium score. Heart. 2015;101:436-41.

53. Boyman O, Kolios AG, Raeber ME. Modulation of T cell responses by IL-2 and IL-2 complexes. Clin Exp Rheumatol. 2015;33:S54-7.

54. Feng YH, Zhou WL, Wu QL, Li XY, Zhao WM, Zou JP. Low dose of resveratrol enhanced immune response of mice. Acta Pharmacol Sin. 2002;23:893-7.

55. Craveiro M, Cretenet G, Mongellaz C, Matias MI, Caron O, de Lima MCP, Zimmermann VS, Solary E, Dardalhon V, Dulić V, Taylor N. Resveratrol stimulates the metabolic reprogramming of human CD4+ T cells to enhance effector function. Sci Signal. 2017;10:eaal3024.

56. Zwergel C, Valente S, Mai A. DNA Methyltransferases Inhibitors from Natural Sources. Curr Top Med Chem. 2016;16:680-96.

57. Chik F, Szyf M. Effects of specific DNMT gene depletion on cancer cell transformation and breast cancer cell invasion; toward selective DNMT inhibitors. Carcinogenesis. 2011;32:224-32.

58. Fernandes GFS, Silva GDB, Pavan AR, Chiba DE, Chin CM, Dos Santos JL. Epigenetic Regulatory Mechanisms Induced by Resveratrol. Nutrients. 2017;9:1201.

\section{Figures}



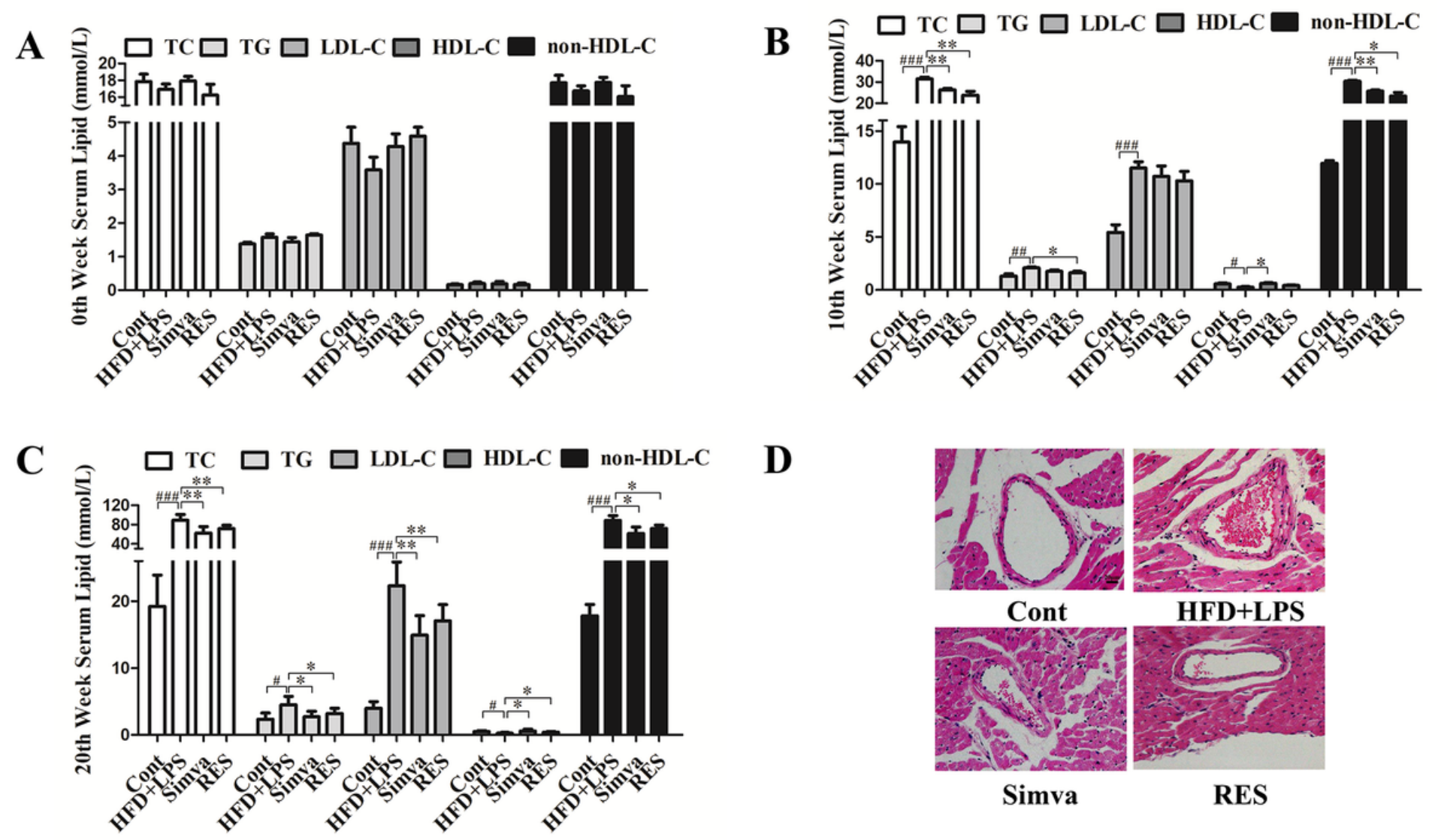

$\mathbf{E}$

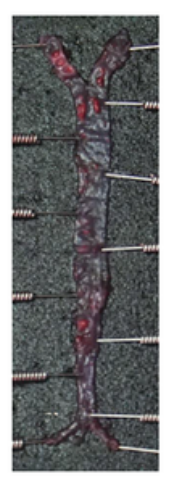

Cont

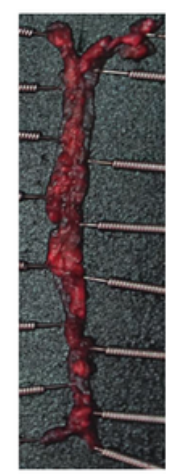

HFD+LPS

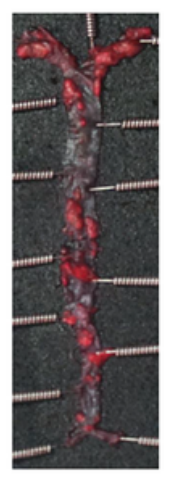

Simva

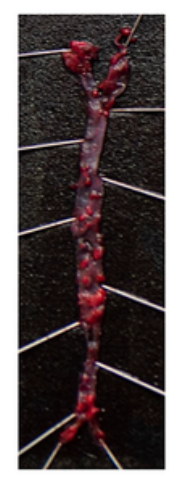

RES

F

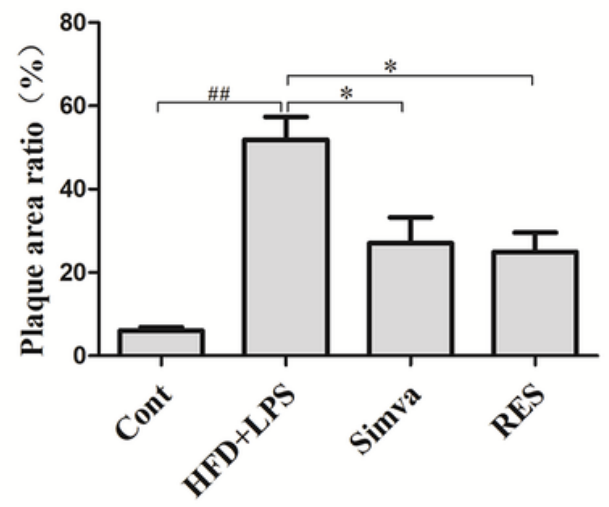

Figure 1

RES inhibited the progression of AS in vivo 
A

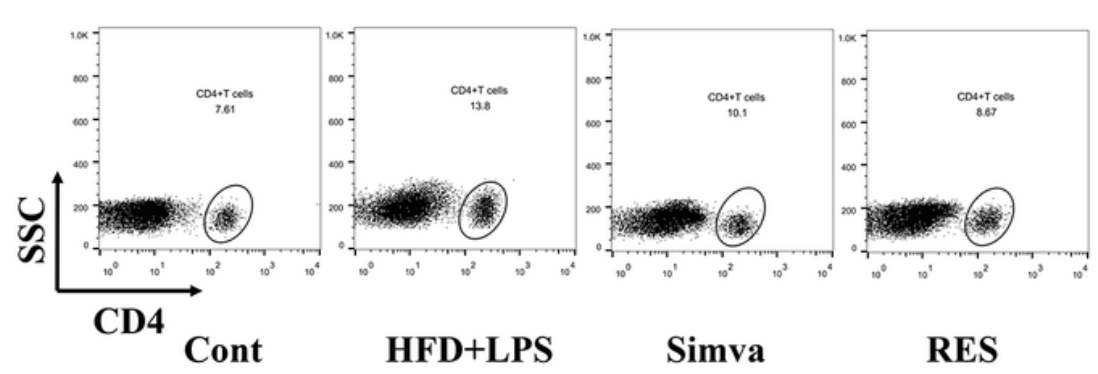

C
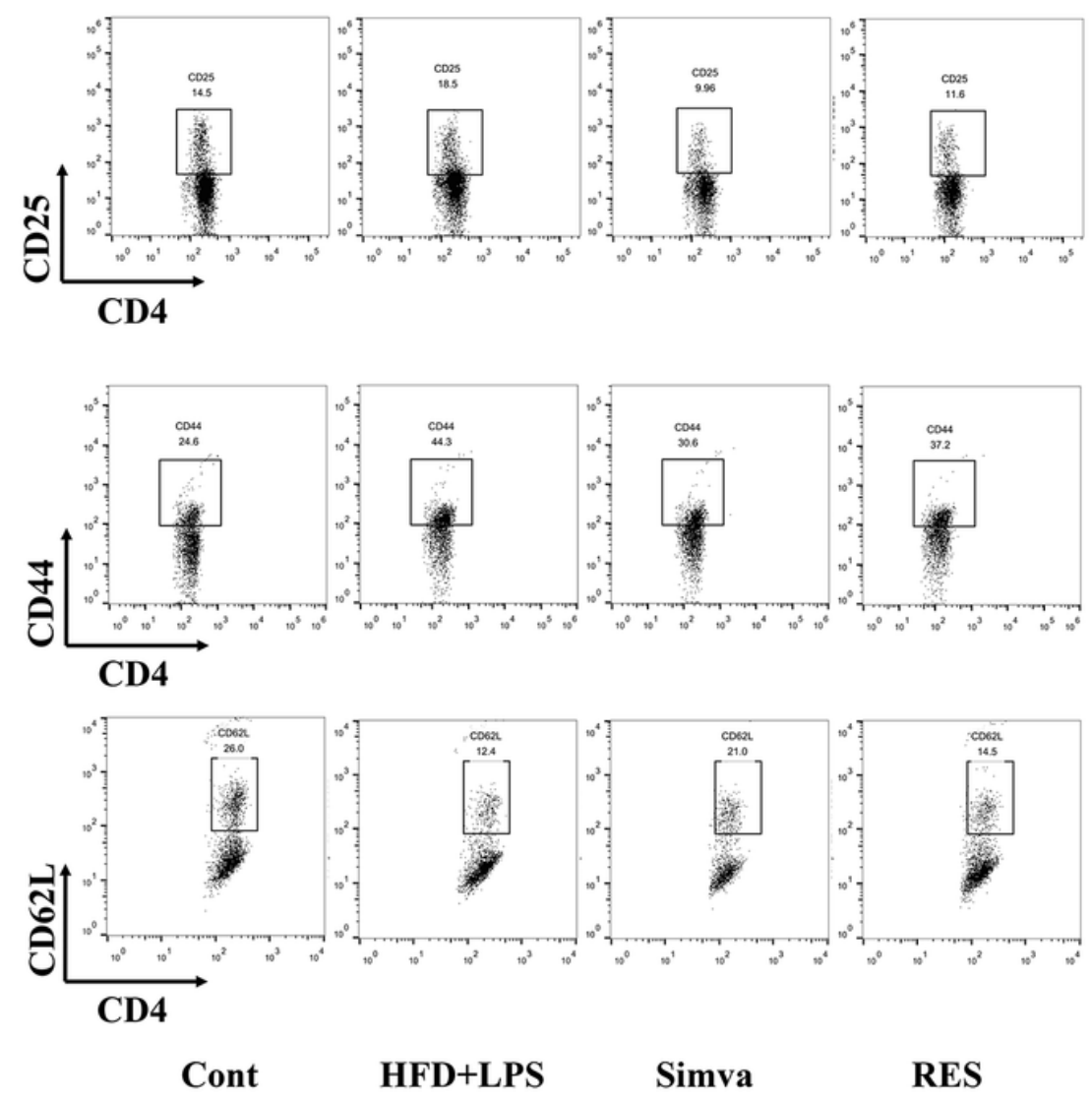

B

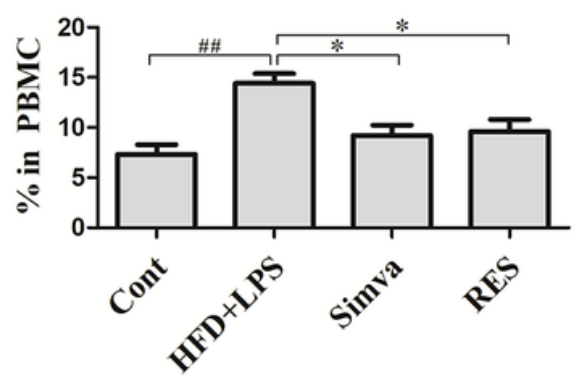

D
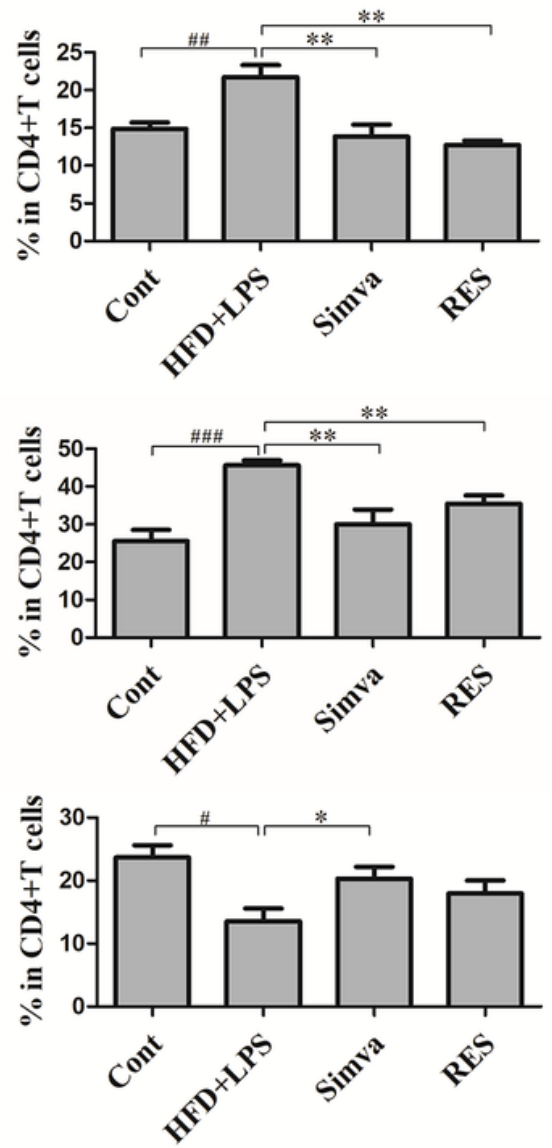

Figure 2

RES affected the frequency and activation of CD $4+T$ cells 


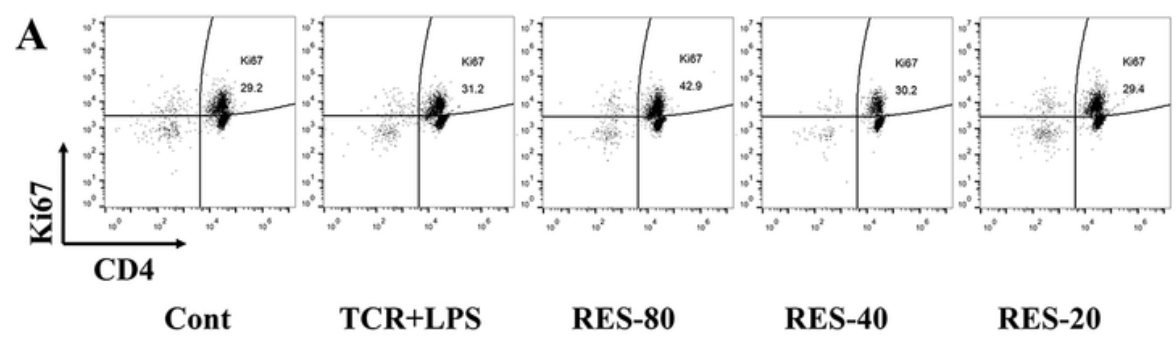

B

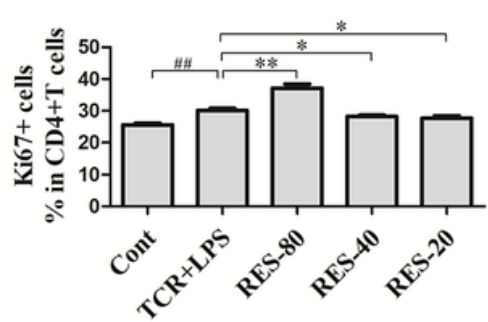

C

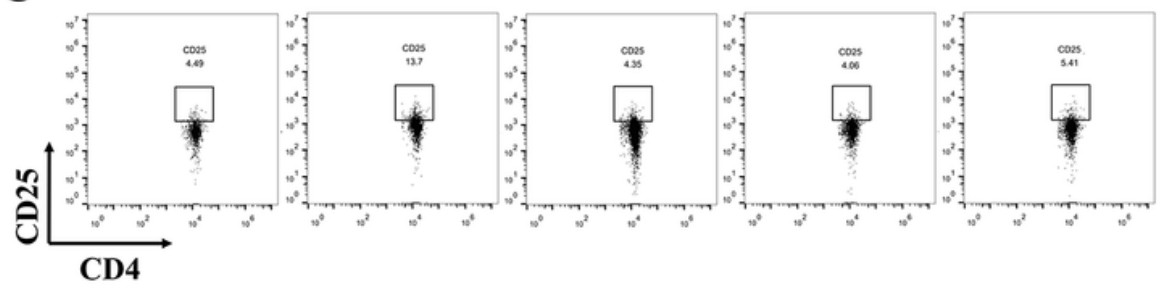

D
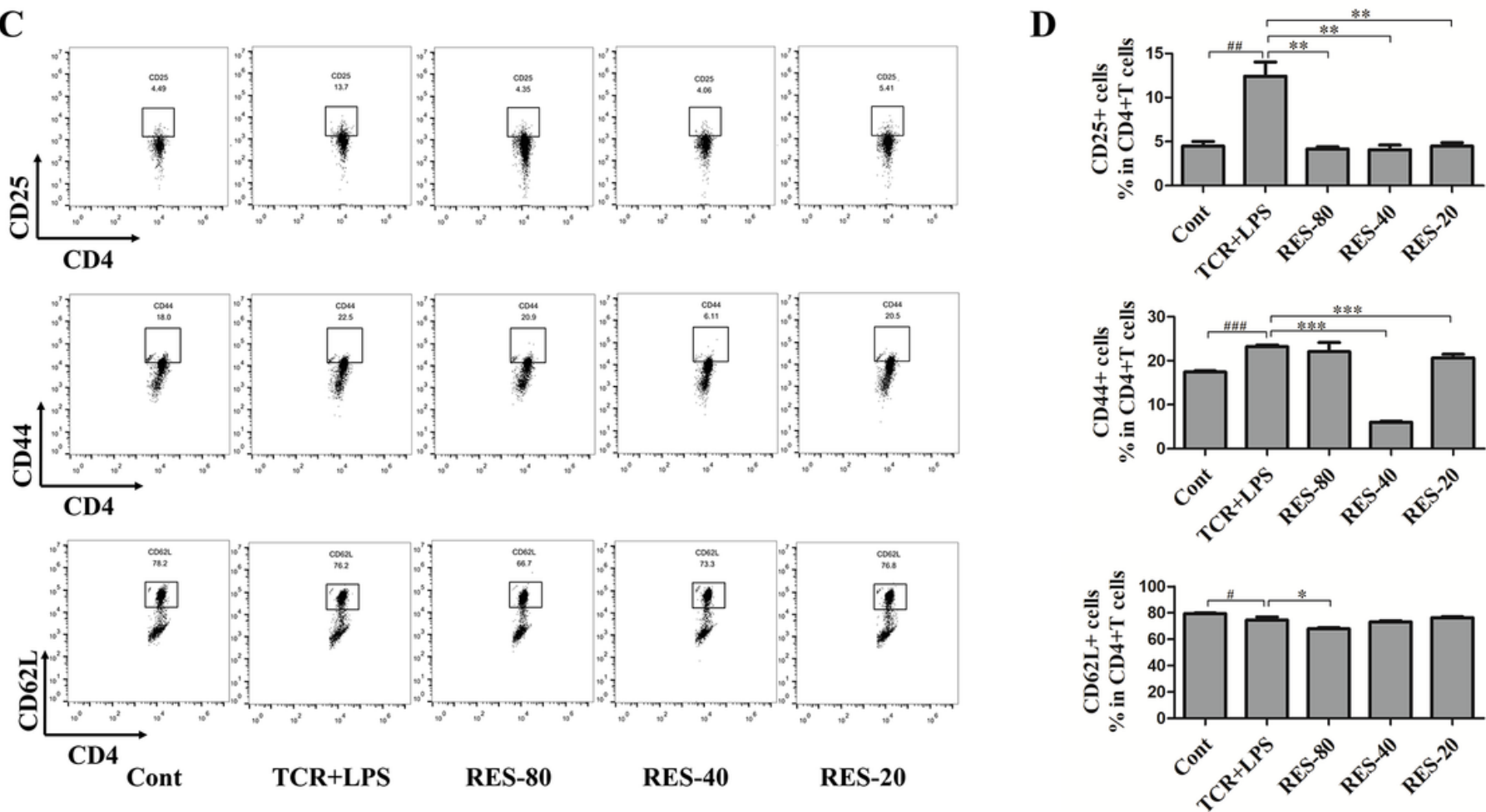

$\mathbf{E}$

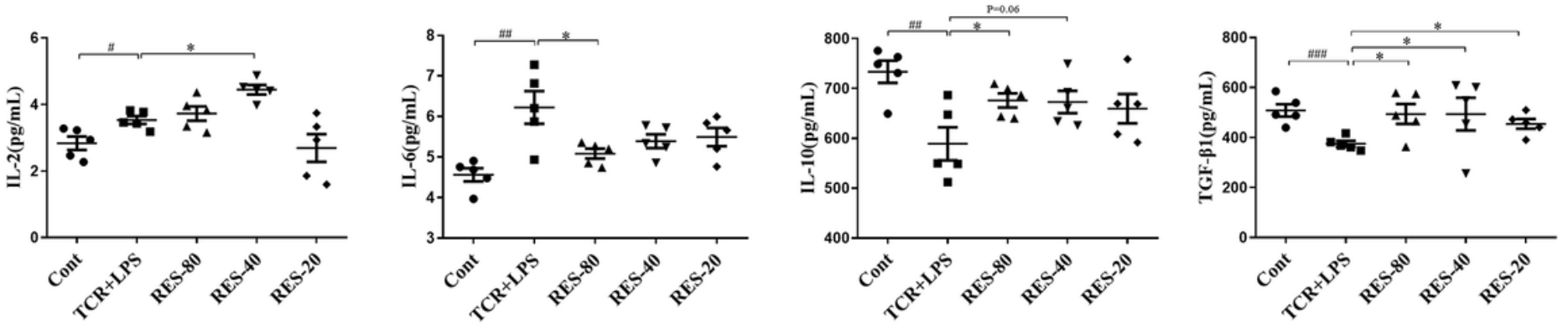

Figure 3

RES influenced the activation of CD4+ T cells in vitro 
A

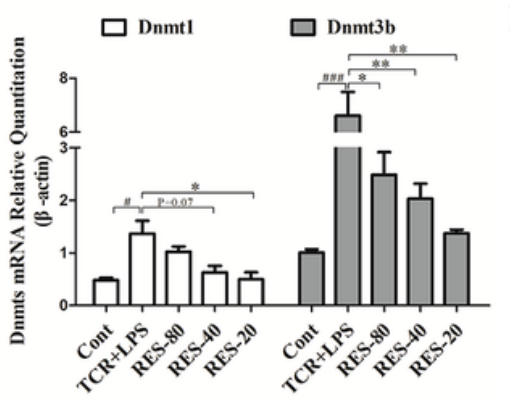

D

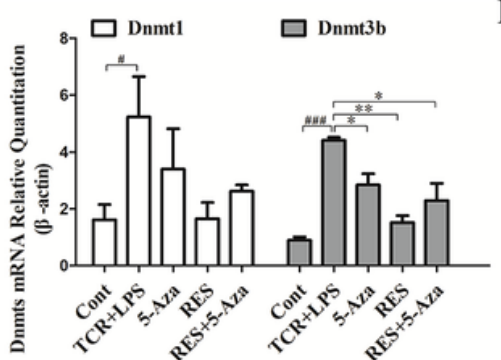

G

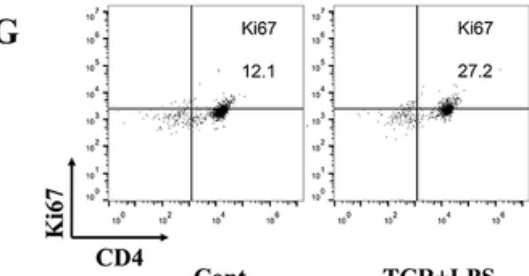

I
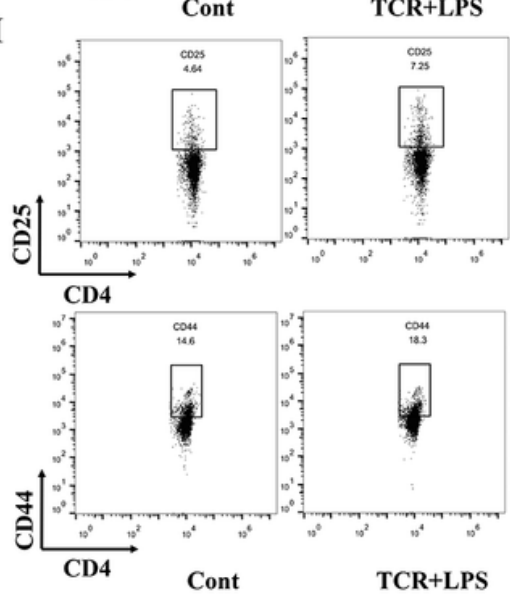

B

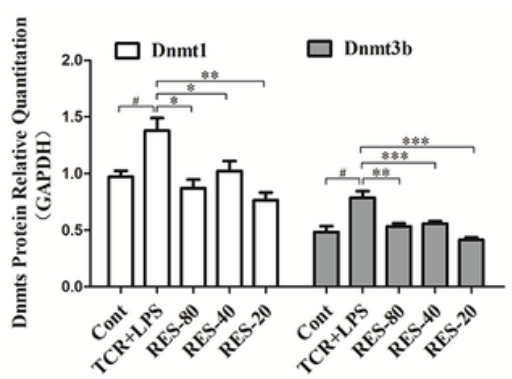

C
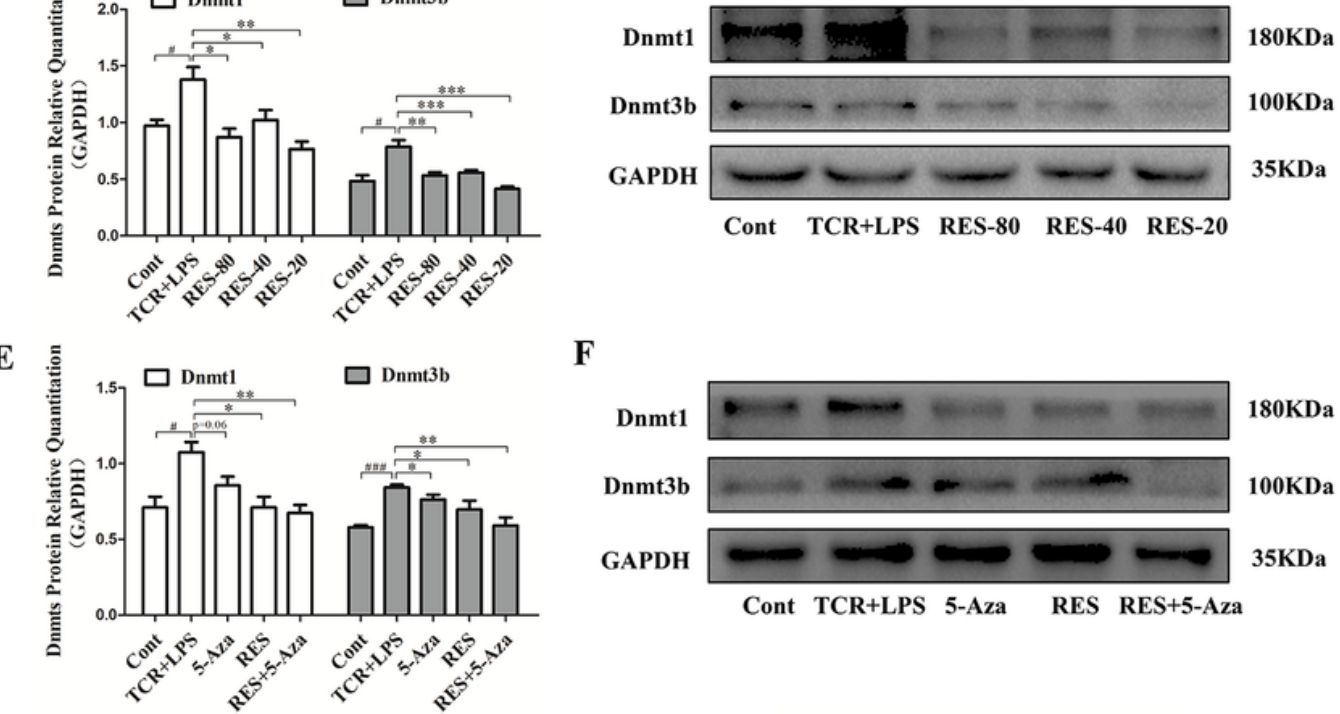

F

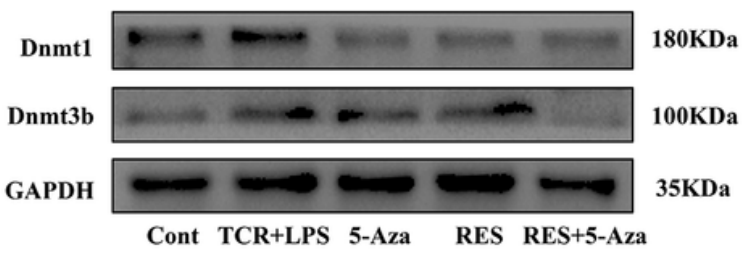

Cont TCR+LPS 5-Aza RES RES+5-Aza

H

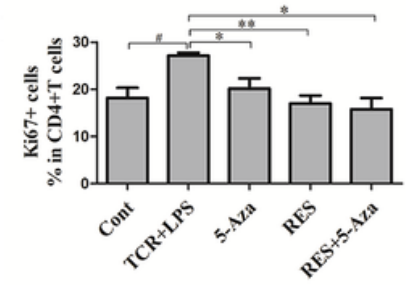

J

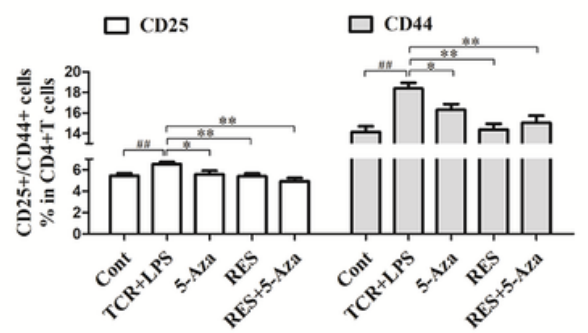

Figure 4

RES influenced the proliferation and activation of CD4+ T cells by inhibiting Dnmt1 and Dnmt3b 